\title{
Urinary Tract Anomalies Associated with MTHFR Gene Polymorphism C677T in Girls
}

\author{
Jana Behunova ${ }^{a}$ Lucia Klimcakova $^{b}$ Ludmila Podracka ${ }^{a}$ \\ a 1st Department of Pediatrics, School of Medicine and Children's University Hospital, and ' Institute of \\ Medical Biology, School of Medicine, University of P.J. Safarik, Kosice, Slovakia
}

\section{Key Words}

MTHFR $\cdot$ C677T $\cdot$ A1298C $\cdot$ Urinary tract anomalies $\cdot$ Sex

differences $\cdot$ Methylation

\begin{abstract}
Background/Aims: Periconceptional folate has a preventive effect not only on neural tube defects, but possibly also on other birth defects such as urinary tract anomalies (UTA), orofacial clefts and conotruncal heart defects. Folate metabolism gene variants are therefore being investigated as potential susceptibility factors. Methods: We assessed the methylenetetrahydrofolate reductase (MTHFR) gene C677T and A1298C genotypes in 132 UTA patients and 290 controls, also with respect to sex. Results: We found a significantly higher incidence of the T allele/TT genotype of the C677T polymorphism in UTA patients compared with controls $(p=$ $0.019 / p=0.044$ ). In the individual sexes, the T allele frequency in UTA girls versus control girls was 42.6 versus $21.7 \%$, $\mathrm{p}<$ 0.0001 ( $\mathrm{OR}=2.68 ; 95 \% \mathrm{Cl}: 1.63-4.40)$, and the frequency of TT genotypes was 19.2 versus $5.6 \%, p=0.02$ (OR $=4.0 ; 95 \%$ $\mathrm{Cl}$ : 1.26-12.69); no difference was observed between the boys' groups. Conclusion: The higher incidence of the C677T MTHFR gene polymorphism in girls with UTA could point to a developmental difference between the sexes that might be related to sexual dimorphism in methylation due to the
\end{abstract}

lower activity of MTHFR in the system with the highest sexual dimorphism: the urogenital system. Naturally, this assumption should be further tested.

Copyright $\odot 2011$ S. Karger AG, Basel

\section{Introduction}

Folate supplementation during the periconceptional period can prevent the occurrence or recurrence of not only up to $40-80 \%$ of neural tube defects (NTD) cases [1, 2] but also certain other birth defects such as orofacial clefts, conotruncal heart defects or urinary tract anomalies $(\mathrm{UTA})^{1}[3-8]$. Thus, genetic variants of folate metabolism could be possible candidates for genetic susceptibility to these multifactorial anomalies. Folate metabolism gene variants have already been investigated with differing results in families with orofacial clefts [9-11] and heart defects [12-14], with the methylenetetrahydrofolate reductase (MTHFR) gene polymorphism C677T

\footnotetext{
1 Given its frequent use in the text, we opted for the shorter, more practical abbreviation 'UTA' for the group of all congenital urinary tract anomalies, though the meaning is equivalent to 'CAKUT' (congenital anomalies of kidney and urinary tract), an acronym used in some of the related literature.
}

\section{KARGER}

Fax +4161306 1234 E-Mail karger@karger.ch www.karger.com
Jana Behunova, $\mathrm{MD}, \mathrm{PhD}$

1st Department of Pediatrics, Children's University Hospital

University of P.J. Safarik (UPJS), Tr. SNP 1

SK-040 66 Kosice (Slovakia)

Tel. +421 55640 4129, E-Mail jana.behunova@ upjs.sk 
being among the most significant (but also the most investigated) according to reviews/meta-analyses $[15,16]$. The C677T polymorphism (rs1801133, coding position after a new renumbering c. $665 \mathrm{C}>\mathrm{T}$, but the original position c.677C $>\mathrm{T}$ is still widely used) leads to a change in one amino acid in protein p.A222 $\mathrm{V}$ and results in MTHFR enzyme thermolability, a reduction of its activity by up to $35-50 \%$ and higher concentrations of homocysteine in homozygotes $[17,18]$. Depending on the C677T genotype, TT homozygotes require a higher intake of folate to reach the same homocysteinemia [19]. Similarly, the A1298C polymorphism (rs1801131, coding position after a new renumbering c.1286A $>$ C) leads to a change in one amino acid in protein p.E429A and slightly lowers MTHFR activity in the mutant allele in homozygotes by up to $60 \%$ [20]. The MTHFR A1298C polymorphism is not associated with hyperhomocysteinemia in homozygotes, but it becomes important in combination with the C677T polymorphism; heterozygotes for both polymorphisms have higher plasmatic concentrations of homocysteine and lower MTHFR activity compared with heterozygotes for only one polymorphism $[20,21]$

Despite definite evidence that folate has a preventive effect regarding some birth defects, the exact mechanism of this effect is still not fully clear. Recent findings emphasize the importance of methylation capability due to DNA methylation and gene expression regulation [2224]. In this context, MTHFR activity is of significant importance as it serves as a checkpoint between methylation capabilities on the one hand and thymidine or purine synthesis on the other. As it is known that gene methylation processes are considerably sex-specific - concerning either physiologic dimorphism or complex diseases [2527] - we can assume that it would be of interest to follow sex-related differences within various groups of nonsyndromic birth defects. Our objectives were to determine the C677T and A1298C MTHFR gene polymorphisms in patients with UTA (also with respect to sex).

\section{Subjects and Methods}

\section{Cases and Controls}

UTA Group. This group included 132 patients: 85 boys (64.4\%) and 47 girls ( $35.6 \%$; boys to girls: $\mathrm{p}=0.009, \mathrm{OR}=1.76$; the sex ratio in our UTA group was consistent with generally reported data, with a predominance of male gender). The patients were recruited from 2006 to 2009 from the inpatient pediatric department and the outpatient nephrological clinic of a University children's hospital, a tertiary center in Kosice, East Slovakia. The major anomalies (52\%) were obstructive anomalies (hydronephrosis, megaure- ter), while nonobstructive kidney anomalies (unilateral agenesis, hypoplasia, non-PKD cysts) represented $25 \%$. The remaining $23 \%$ of cases were defects of the ureter-bladder connection, mostly vesicoureteral reflux or a double ureter. The average age of the patients was 6.2 years (range: $0-19$ ). Children with multiple birth defects or suspected monogenic disorders were not included.

Population Control Group. This group consisted of 290 unselected and unrelated newborns, consecutively born within 4 months at the Faculty Hospital Kosice, Slovakia: 147 boys (50.7\%) and 143 girls (49.3\%). A capillary dry blood spot was taken together with newborn blood screening to minimize the trauma. The parents of both patients and control newborns signed an informed consent form, and the entire clinical study was approved by the Ethics Committee of Safarik University School of Medicine.

\section{Genotyping and Statistics}

Genomic DNA from patients was extracted from whole venous blood in EDTA using the Promega Wizard Genomic DNA Purification Kit (Promega Corp., Madison, Wisc., USA). DNA from control newborns was extracted from dry blood spots using the method described previously [28]. All samples were genotyped by real-time PCR for both C677T and A1298C using a LightCycler 1.5 Instrument Roche (F. Hoffmann-La Roche Ltd., Basel, Switzerland) and commercial kits from Roche and Tib Molbiol (Berlin, Germany), following the manufacturers' instructions.

Genotype frequencies in the patient and control groups were compared using Pearson's $\chi^{2}$ test or (if the number of samples did not fulfill its criteria) Fisher's exact test. The OR was rated using Gart's exact method. The statistical significance level for all tests was determined $(\alpha=0.05)$. We used Arcus QuickStat Biomedical statistical software ver. 1.1 (Arcus Statistical Software, Research Solutions, Addison Wesley Longman Ltd. USA) and Statistica Cz. 6.1 (Statsoft s.r.o., Prague, Czech Republic).

\section{Results}

Table 1a displays the C677T genotypes and allele frequencies in the UTA patients and the control Slovak population newborns, including the frequencies in the females and males of each group. Table $1 \mathrm{~b}$ displays the same data for the A1298C polymorphism. There was no deviation from Hardy-Weinberg equilibrium for either the C677T or the A1298C polymorphism in the control population. We did not observe any significant differences between the sexes in the control groups; however, there was a nearly significant higher frequency of the $\mathrm{C}$ allele and CC genotype of the C677T polymorphism in girls when compared with boys $(\mathrm{p}=0.056, \mathrm{OR}=1.45$, 95\% CI: $0.97-2.15$; and $\mathrm{p}=0.054, \mathrm{OR}=1.58,95 \% \mathrm{CI}$ : $0.965-2.596)$.

In the group of patients with UTA, we observed a significantly higher incidence of the $\mathrm{C} 677 \mathrm{~T}$ polymorphism 
Table 1. Genotype and allele frequencies of the MTHFR polymorphisms C677T and A1298C in the groups of UTA patients and the control population of Slovak newborns

a C677T polymorphism

\begin{tabular}{|c|c|c|c|c|c|c|}
\hline & & $\mathrm{CC}$ & $\mathrm{CT}$ & TT & All & $\mathrm{T}$ \\
\hline UTA all & $\mathrm{n}(\%)$ & $62(46.97)$ & $53(40.15)$ & $17(12.88)$ & 132 & 0.33 \\
\hline UTA F & $\mathrm{n}(\%)$ & $16(34.0)$ & $22(46.8)$ & $9(19.2)$ & 47 & 0.426 \\
\hline UTA M & $\mathrm{n}(\%)$ & $46(54.12)$ & $31(36.47)$ & $8(9.41)$ & 85 & 0.276 \\
\hline Control all & $\mathrm{n}(\%)$ & $164(56.5)$ & $106(36.6)$ & $20(6.9)$ & 290 & 0.252 \\
\hline Control F & $\mathrm{n}(\%)$ & $89(62.2)$ & $46(32.2)$ & $8(9.8)$ & 143 & 0.217 \\
\hline Control M & $\mathrm{n}(\%)$ & $75(51.0)$ & $60(40.8)$ & $12(8.2)$ & 147 & 0.286 \\
\hline UTA all vs. & $\mathrm{p}(\mathrm{OR})$ & $0.07(0.68)$ & $0.48(1.17)$ & $0.044(1.996)$ & $0.06\left(\chi^{2}=5.57\right)$ & $0.019(1.46)$ \\
\hline control all & $95 \% \mathrm{CI}$ & $0.45-1.03$ & $0.76-1.78$ & $1.01-3.95$ & 2 d.f. & $1.06-2.01$ \\
\hline UTA F vs. & $\mathrm{p}(\mathrm{OR})$ & $0.0007(0.31)$ & $0.069(1.86)$ & $0.02(4.0)+$ & $0.0007\left(\chi^{2}=14.47\right)$ & $<0.0001(2.68)$ \\
\hline control F & $95 \% \mathrm{CI}$ & $0.16-0.63$ & $0.95-3.63$ & $1.26-12.69$ & 2 d.f. & $1.63-4.40$ \\
\hline UTA M vs. & $\mathrm{p}(\mathrm{OR})$ & $0.65(1.13)$ & $0.51(0.83)$ & $0.74(1.17)$ & $0.796\left(\chi^{2}=0.46\right)$ & $0.83(0.96)$ \\
\hline control M & $95 \% \mathrm{CI}$ & $0.66-1.93$ & $0.48-1.44$ & $0.46-2.98$ & 2 d.f. & $0.63-1.46$ \\
\hline UTA F vs. & $\mathrm{p}(\mathrm{OR})$ & $0.027(0.44)$ & $0.25(1.53)$ & $0.11(2.28)$ & $0.059\left(\chi^{2}=5.63\right)$ & $0.01(1.94)$ \\
\hline UTA M & $95 \% \mathrm{CI}$ & $0.21-0.92$ & $0.74-3.16$ & $0.82-6.38$ & 2 d.f. & $1.14-3.29$ \\
\hline Control F vs. & $\mathrm{p}(\mathrm{OR})$ & $0.054(1.58)$ & $0.13(0.69)$ & $0.39(0.67)$ & $0.15\left(\chi^{2}=3.79\right)$ & $0.06(0.69)$ \\
\hline control M & $95 \% \mathrm{CI}$ & $0.99-2.53$ & $0.43-1.11$ & $0.26-1.68$ & 2 d.f. & $0.47-1.01$ \\
\hline
\end{tabular}

A1298C polymorphism

\begin{tabular}{|c|c|c|c|c|c|c|}
\hline & & AA & AC & $\mathrm{CC}$ & All & $\mathrm{C}$ \\
\hline UTA all & n (\%) & $67(50.76)$ & $50(37.88)$ & $15(11.36)$ & 132 & 0.303 \\
\hline UTA F & n (\%) & $21(44.68)$ & $18(38.30)$ & $8(17.02)$ & 47 & 0.362 \\
\hline UTA M & n (\%) & $46(54.12)$ & $32(37.65)$ & $7(8.24)$ & 85 & 0.271 \\
\hline Control all & n (\%) & $129(44.48)$ & $121(41.73)$ & 40 (13.79) & 290 & 0.347 \\
\hline Control F & n (\%) & $70(48.95)$ & $56(39.16)$ & $17(11.89)$ & 143 & 0.315 \\
\hline Control M & $\mathrm{n}(\%)$ & $59(40.14)$ & $65(44.21)$ & $23(15.65)$ & 147 & 0.378 \\
\hline UTA all vs. & $\mathrm{p}(\mathrm{OR})$ & $0.23(1.29)$ & $0.46(0.85)$ & $0.49(0.80)$ & $0.47\left(\chi^{2}=1.51\right)$ & $0.21(0.82)$ \\
\hline control all & $95 \% \mathrm{CI}$ & $0.85-1.94$ & $0.56-1.30$ & $0.43-1.51$ & 2 d.f. & $0.60-1.12$ \\
\hline UTA F vs. & $\mathrm{p}(\mathrm{OR})$ & $0.61(0.84)$ & $0.92(0.96)$ & $0.37(1.52)$ & $0.65\left(\chi^{2}=0.85\right)$ & $0.4(1.23)$ \\
\hline control F & $95 \% \mathrm{CI}$ & $0.43-1.63$ & $0.49-1.90$ & $0.61-3.79$ & 2 d.f. & $0.76-2.01$ \\
\hline UTA M vs. & $\mathrm{p}(\mathrm{OR})$ & $0.039(1.76)$ & $0.33(0.76)$ & $0.11(0.48)$ & $0.08\left(\chi^{2}=5.17\right)$ & $0.019(0.61)$ \\
\hline control M & $95 \% \mathrm{CI}$ & $1.03-3.02$ & $0.44-1.32$ & $0.20-1.18$ & 2 d.f. & $0.40-0.92$ \\
\hline UTA F vs. & $\mathrm{p}(\mathrm{OR})$ & $0.3(0.68)$ & $0.94(1.03)$ & $0.13(2.29)$ & $0.27\left(\chi^{2}=2.59\right)$ & $0.12(1.53)$ \\
\hline UTA M & $95 \% \mathrm{CI}$ & $0.34-1.40$ & $0.49-2.14$ & $0.77-6.76$ & 2 d.f. & $0.89-2.62$ \\
\hline Control F vs. & $\mathrm{p}(\mathrm{OR})$ & $0.13(1.43)$ & $0.38(0.81)$ & $0.35(0.73)$ & $0.29\left(\chi^{2}=2.45\right)$ & $0.11(0.76)$ \\
\hline control M & $95 \%$ CI & $0.89-2.28$ & $0.51-1.29$ & $0.37-1.43$ & 2 d.f. & $0.53-1.07$ \\
\hline
\end{tabular}

$+=$ Fisher's exact test; d.f. $=$ degrees of freedom.

in comparison with the control population - for both the $\mathrm{T}$ allele and the TT genotype. These contrasts were even more significant when analyzing the sexes separately: the $\mathrm{T}$ alleles in the group of UTA girls compared with those of the control girls were 42.55 versus $21.68 \%$ ( $p<0.0001$, $\mathrm{OR}=2.68)$, and the TT genotypes were 19.20 versus $5.59 \%(\mathrm{p}=0.02, \mathrm{OR}=4.0)$. In contrast, the UTA boys did not show any significant difference in comparison with the control boys (fig. 1). When we compared C677T between the sexes within the UTA group, we also found significant differences: the $\mathrm{T}$ allele occurred more frequently in the UTA girls in comparison with the UTA boys $(\mathrm{OR}=1.94)$, while the wild-type genotype CC was less abundant in the UTA girls than in the UTA boys 
Fig. 1. C677T polymorphism genotypes (a, b) and alleles (c, d) of UTA girls compared to control girls $(\mathbf{a}, \mathbf{c})$, and UTA boys compared to control boys $(\mathbf{b}, \mathbf{d})$.

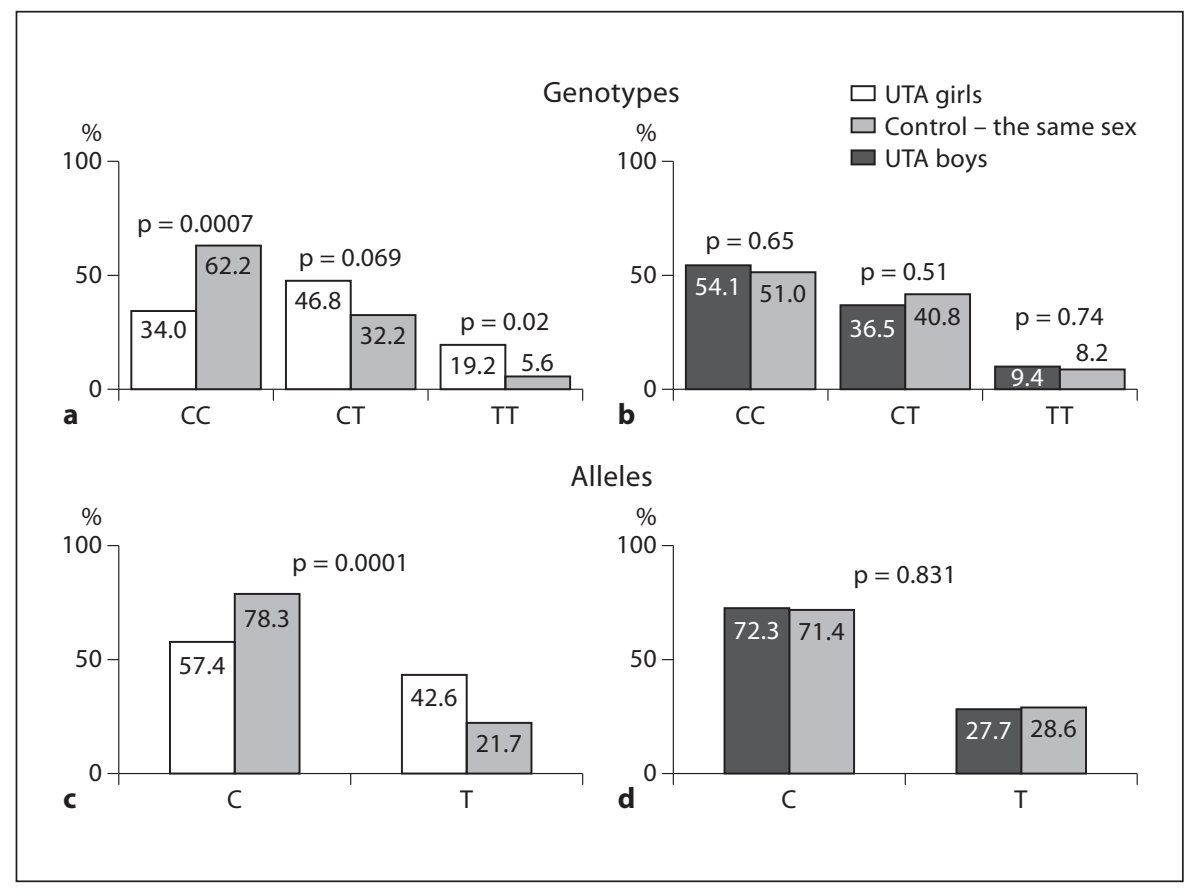

$(\mathrm{OR}=0.44)$. The other specific genotypes showed no statistically significant differences. When investigating the A1298C MTHFR gene polymorphism, we did not find any association with UTA.

\section{Discussion}

This study has determined, for the first time to our knowledge, the incidence of the MTHFR gene polymorphisms C677T and A1298C in a group of patients with UTA and compares it with a control group, including with regard to sex differences.

We decided to analyze patients with UTA for the MTHFR gene polymorphisms C677T and A1298C as a result of other works presenting UTA incidence reduction after folate supplementation. The first paper on this topic was a double-blind Hungarian study [3] with periconceptional administration of multivitamins containing $0.8 \mathrm{mg}$ folate versus placebo in a group of more than 4,000 pregnant women. They found a significantly lower incidence of total birth defects (excluding NTD and known genetic syndromes) in the group of newborns with folate administration compared to the placebo group. The largest differences were found in the incidence of limb anomalies, UTA (renal agenesis and obstructive uropathies), pylorostenosis and cardiovascular malformations, although the differences in the individual groups were not statistically significant due to the low number of patients.

Another study, a case-control from the USA, confirmed the significant reduction of UTA after periconceptional supplementation with multivitamins containing folate [29]. Further work, again a retrospective casecontrol study, confirmed a significantly lower incidence of UTA, isolated cleft palate and limb defects in the offspring of mothers receiving periconceptional multivitamins [30]. The authors, however, cannot exclude the positive influence of other vitamins in multivitamin mixtures in combination with folate. Despite these data, MTHFR gene polymorphisms have not yet been evaluated, to the best of our knowledge, in UTA patients.

The results of our analysis of UTA patients were surprising, especially after we had not previously found any association of MTHFR gene polymorphisms with NTD when analyzing a group of 93 NTD patients with the same control group [28]. In contrast, in the analyzed group of 132 patients with UTA, the incidence of the TT mutant C677T genotype was nearly twice as high as in the 290 newborn controls. We found even more significant differences when comparing the C677T genotypes with respect to sex. There was a significantly higher frequency of the C677T mutant allele and a significantly 
lower frequency of the wild-type CC genotype in the group of UTA girls than in the UTA boys.

The data were even more prominent when we compared the incidence of C677T in UTA patients of the same sex and the control group. In females, the differences between the patients and the controls were highly significant, while in boys, there were no differences at all. However, we are aware of the fact that there is a large difference (although nonsignificant) in C677T frequency between the boys and girls in the control group (in the mean of lower occurrence of the T mutant allele in girls), which could have led to some of the observed differences between the cases and the controls. In addition, we did not have the opportunity to re-evaluate the control group later during childhood. Thus, although the results of newborn UTA screening (renal ultrasound) did not reveal any obvious structural abnormalities in the control group, a small proportion of UTA could have been missed by the screening, mainly I-III grade vesicoureteral reflux.

The MTHFR gene lies on an autosome, and to our knowledge, no variances in this enzyme's activity have been described that would suggest sex differences, except the gender-different influence of the MTHFR genotype on thiopurine S-methyltransferase (TPMT) activity [31]. However, Rozen et al. [32] mention a substantial reduction in female infants with the homozygous mutant MTHFR $677 \mathrm{C}->$ T genotype in two independent sets of control newborns randomly selected as controls for a spina bifida study and a cleft lip and palate study. Interestingly, the percentage in the case of the females (either spina bifida, or cleft lip and palate) did not vary by MTHFR genotype. They considered the decreased viability in utero for $677 \mathrm{C}->\mathrm{T}$ homozygotes as one possible interpretation, especially in female fetuses. Also, our previous analyses did not show any significant sex differences in the distribution of MTHFR polymorphisms in NTD patients [28]. The findings in UTA patients thus suggest the possibility of sex-differentiated interactions of the MTHFR enzyme (resp. folate metabolism) in urinary tract (UT) development. We could not compare these results with any similar work, however, as we did not find any information on the possible influence of MTHFR activity or folate metabolism-specific issues on UT development in humans or in experiments. As a consequence, we can only assume the possible involvement of reduced MTHFR activity in the failure of sex-dimorphic processes during UT development.

Our study does have some limitations. First of all, the data were obtained in a cross-sectional manner, with a relatively small sample size of the studied cohort (mainly
UTA girls). This was influenced by the fact that patients were recruited from only one center (albeit a tertiary pediatric nephrologic-urologic center serving the whole of East Slovakia), and the much lower incidence of UTA in female gender. Furthermore, there was noncompliance of ages and origins among the study participants (cases and controls) - the controls came from a series of consecutive births within 4 months at a neonatal department in the same tertiary center. Nevertheless, even taking these limitations into consideration, we can assume that there may not be any significant differences in polymorphism frequencies in a small region and a freely mixing population such as East Slovakia (1.6 million people). It is also unlikely that a significant genotype drift has emerged during the last 15 years, which was the maximum age of the majority of UTA patients. There has never been a folate campaign or flour fortification with folate in Slovakia, and we did not get any information about periconceptional folate intake in the mothers of cases or controls.

A further limitation of the study is the combined grouping of the various UTA phenotypes: the sample included patients with obstructive UTA (52\%) together with nonobstructive kidney anomalies (25\%) and nonobstructive defects of the ureter-bladder connection (23\%). This representation of phenotypes could potentially have an effect on the study results and generalizations drawn from it since the individual types of UTA might differ in the mechanisms of their formation. We did not assess the polymorphisms in the three UTA subgroups separately because of the substantially limited sample in the subgroups, especially after dividing them by sex. However, a significantly higher incidence of the C677T MTHFR gene polymorphism in UTA patients was found in the whole cohort studied.

It should be noted that there are a number of genes involved in urinary system development, and their complex analysis is not a subject of this paper. However, we can state that to our knowledge, no UT developmental factor or UTA animal model related to folate metabolism has yet been described [33-42]. Briefly, UT development in general consists of two main processes. The first is metanephros and ureteric bud (a part of Wolffian/nephric duct) development from intermediate mesoderm cells (survival factor Pax2, counteracting the apoptosis molecule TGFb2) $[33,34]$ and their mutual induction ('budding') - the formation of a definite kidney and ureter with (1) the positive support of budding, assured mainly by the GDNF (glial-derived neurotrophic factor)-Wnt11 pathway with receptor complex Ret-GFR $\alpha 1$ and other positive regulators, e.g. gremlin 1 [34-37], and (2) the 
counteractors of 'budding' and GDNF activity with inhibition of cell proliferation, the failure of which leads to ectopic ureters, a double-collecting system, hydroureter and hydronephrosis (mainly BMP4), and others [37-39]. The second major process is urogenital sinus (cloaca) development from endodermal cells, forming a definite urinary bladder, ureter-bladder connection and urethra (gene regulation, e.g. by Aldh1a2, PTPRF, PTPRS, NFIa, L1-CAM and others) [40-42]. The UT is also developmentally linked with the genitals, mostly through key Müllerian and Wolffian duct regulators [35]. Interestingly, according to one case-control study, folic acid use in the first 3 months of pregnancy also significantly reduced the risk of hypospadias (471 cases vs. 490 controls) [43].

From a biochemical point of view, MTHFR is a key checkpoint between two important cycles resulting subsequently in either DNA methylation (through methionine synthesis) or DNA synthesis (thymidylate nucleotides and purine bases) [44]. Reduced MTHFR activity shifts the balance toward the side of thymidylate synthesis, which could have unfavorable consequences on DNA methylation. DNA methylation is one of the major epigenetic mechanisms influencing embryonic development and sex-specific reprogramming [45-47]. The sex specificity of methylation reactions definitely pertains to the mechanisms underlying sexual dimorphism [27]. These principles could also influence sex differences in the incidence of some birth defects and their severity and trait-transmitting [48]. Based on this, we can presume that the reduced methylation potential in girls with the
C677T mutant variant might (together with other concurrent risk factors) possibly participate in the disruption of UT development. Naturally, this 'hypomethylation' hypothesis needs to be supported by larger studies and eventually in an experiment.

\section{Summary}

This is the first study conducted on the most common MTHFR gene polymorphisms, C677T and A1298C, in relation to UTA. The analysis found an association between the C677T polymorphism and UTA, with a much higher significance in girls. These results might indirectly point to the potential role of folate metabolism perturbations (reduced MTHFR activity and methylation reactions) in UTA pathogenesis, particularly in females. This might also emphasize the urgent need for adequate folate intake for all women of fertile age.

\section{Acknowledgements}

Many thanks to Dr. Jaroslava Capova and the Department of Neonatology team for their help in obtaining the control neonatal samples. The following grants were received: VEGA MŠ SR grant No. 1/3362/06, VEGA MŠ SR grant No. 1/0805/08 and VEGA MŠ SR grant No. 1/0525/10 [VEGA MŠ SR: Vedecká Grantová Agentúra Ministerstva Školstva Slovenskej Republiky (Scientific Grant Agency of the Ministry of Education of the Slovak Republic)].

\section{References}

1 Prevention of neural tube defects: results of the Medical Research Council Vitamin Study. MRC Vitamin Study Research Group. Lancet 1991;338:131-137.

-2 Berry RJ, Li Z, Erickson JD, Li S, Moore CA, Wang $\mathrm{H}$, Mulinare J, Zhao P, Wong LY, Gindler J, Hong SX, Correa A: Prevention of neural-tube defects with folic acid in China. N Engl J Med 1999;341:1485-1490.

-3 Czeizel AE: Prevention of congenital abnormalities by periconceptional multivitamin supplementation. BMJ 1993;306:1645-1648.

-4 Shaw GM, Lammer EJ, Wasserman CR, O'Malley CD, Tolarova MM: Risks of orofacial clefts in children born to women using multivitamins containing folic acid periconceptionally. Lancet 1995;396:393-396.

5 Shaw GM, O'Malley CD, Wasserman CR, Tolarova MM, Lammer EJ: Maternal periconceptional use of multivitamins and re- duced risk for conotruncal heart defects and limb deficiencies among offspring. Am J Med Genet 1995;59:536-545.

6 Botto LD, Khoury MJ, Mulinare J, Erickson JD: Periconceptional multivitamin use and the occurrence of conotruncal heart defects: results from a population-based, case-control study. Pediatrics 1996;98:911-917.

7 Goh I, Bollano E, Einarson TR, Koren G: Prenatal multivitamin supplementation and rates of congenital anomalies: a meta-analysis. J Obstet Gynaecol Can 2006;28:680689.

8 Czeizel AE: Periconceptional folic acid and multivitamin supplementation for the prevention of neural tube defects and other congenital abnormalities. Birth Defects Rese A Clin Mol Teratol 2009;85:260-268.

-9 Jugessur A, Wilcox AJ, Lie RT, Murray JC, Taylor JA, Ulvik A, Drevon CA, Vindenes
HA, Åbyholm FE: Exploring the effects of methylenetetrahydrofolate reductase gene variants C677T and A1298C on the risk of orofacial clefts in 261 Norwegian case-parent triads. Am J Epidemiol 2003;157:10831091.

10 Boyles AL, Wilcox AJ, Taylor JA, Meyer K, Fredriksen A, Ueland PM, Drevon CA, Vollset SE, Lie RT: Folate and one-carbon metabolism gene polymorphisms and their associations with oral facial clefts. Am J Med Genet A 2008;146:440-449.

-11 Mills JL, Molloy AM, Parle-McDermott A, Troendle JF, Brody LC, Conley MR, Cox C, Pangilinan F, Orr DJ, Earley M, McKiernan E, Lynn EC, Doyle A, Scott JM, Kirke PN: Folate-related gene polymorphisms as risk factors for cleft lip and cleft palate. Birth Defects Res A Clin Mol Teratol 2008;82:636643 
12 Storti S, Vittorini S, Lascone MR, Sacchelli M, Collavoli A, Ripoli A, Cocchi G, Biagini A, Clerico A: Association between 5,10-methylenetetrahydrofolate reductase $\mathrm{C} 677 \mathrm{~T}$ and A1298C polymorphisms and conotruncal heart defects. Clin Chem Lab Med 2003;41: 276-280.

13 Hobbs CA, James SJ, Parsian A, Krakowiak PA, Jernigan S, Greenhaw JJ, Lu Y, Cleves MA: Congenital heart defects and genetic variants in the methylenetetrahydroflate reductase gene. J Med Genet 2006;43:162-166.

- 14 Shaw GM, Lu W, Zhu H, Yang W, Briggs FBS, Carmichael SL, Barcellos LF, Lammer EJ, Finnell RH: 118 SNPs of folate-related genes and risks of spina bifida and conotruncal heart defects. BMC Med Genet 2009;10:49.

15 Botto LD, Yang Q: 5,10-methylenetetrahydrofolate reductase gene variants and congenital anomalies: A HuGE Review. Am J Epidemiol 2000;151:862-877.

-16 Van Beynum IM, den Heijer M, Blom HJ, Kapusta L: The MTHFR $677 \mathrm{C}->$ T polymorphism and the risk of congenital heart defects: a literature review and meta-analysis. QJM 2007;100:743-753.

$\checkmark 17$ Kang SS, Wong PWK, Susmano A, Sora J, Norusis M, Ruggie N: Thermolabile methylenetetrahydrofolate reductase: an inherited risk factor for coronary artery disease. Am J Hum Genet 1991;48:536-545.

-18 Frosst P, Blom HJ, Milos R, Goyette P, Sheppard CA, Mathews RG, Boers GJH, den Heijer M, Kluijtmans LAJ, van den Heuvel LP, Rozen R: A candidate genetic risk factor for vascular disease: a common mutation in methylenetetrahydrofolate reductase. Nat Genet 1995;10:111-113.

19 Ashfield-Watt PAL, Pullin CH, Whiting JM, Clark ZE, Moat SJ, Newcombe RG, Burr ML, Lewis MJ, Powers HJ, McDowell IFW: Methylenetetrahydrofolate reductase $677 \mathrm{C}->\mathrm{T}$ genotype modulates homocysteine responses to a folate-rich diet or a low-dose folic acid supplement: a randomized controlled trial. Am J Clin Nutr 2002;76:180-186.

-20 Weisberg I, Tran P, Christensen B, Sibani S, Rozen R: A second genetic polymorphism in methylenetetrahydrofolate reductase (MTHFR) associated with decreased enzyme activity. Mol Genet Metab 1998;64:169-172.

-21 Van der Put NMJ, Gabreëls F, Stevens EMB, Smeitink JAM, Trijbels FJM, Eskes TKAB, Van den Heuvel LP, Blom HJ: A second common mutation in the methylenetetrahydrofolate reductase gene: an additional risk factor for neural tube defects? Am J Hum Genet 1998;62:1044-1051.

-22 Dunlevy LP, Burren KA, Mills K, Chitty LS, Copp AJ, Greene ND: Integrity of the methylation cycle is essential for mammalian neural tube closure. Birth Defects Res A Clin Mol Teratol 2006;76:544-552.
23 Van der Linden IJ, Heil SG, van Egmont Petersen M, van Straaten HW, den Heijer M, Blom HJ: Inhibition of methylation and changes in gene expression in relation to neural tube defects. Birth Defects Res A Clin Mol Teratol 2008;82:676-683.

24 Blom HJ: Folic acid, methylation and neural tube closure in humans. Birth Defects Res A Clin Mol Teratol 2009;85:295-302.

25 Kaminsky Z, Wang SC, Petronis A: Complex disease, gender and epigenetics. Ann Med 2006;38:530-544.

26 Kwong WY, Miller DJ, Wilkins AP, Dear MS Wright JN, Osmond C, Zhang J, Fleming TP: Maternal low protein diet restricted to the preimplantation period induces a genderspecific change on hepatic gene expression in rat fetuses. Mol Reprod Dev 2007;74:48-56.

27 Vigé A, Gallou-Kabani C, Junien C: Sexual dimorphism in non-Mendelian inheritance. Pediatr Res 2008;63:340-347.

28 Behunova J, Klimcakova L, Zavadilikova E, Potocekova D, Sykora P, Podracka L: Methylenetetrahydrofolate reductase gene polymorphisms and neural tube defects epidemiology in the Slovak population. Birth Defects Res A Clin Mol Teratol 2010;88:695-700.

29 Li DK, Daling JR, Mueller BA, Hickok DE, Fantel AG, Weiss NS: Periconceptional multivitamin use in relation to the risk of congenital urinary tract anomalies. Epidemiology 1995;6:212-218.

30 Werler MM, Hayes C, Louik C, Shapiro S, Mitchell AA: Multivitamin supplementation and risk of birth defects. Am J Epidemiol 1999;150:675-682.

-31 Karas-Kuzelicki N, Milek M, MlinaricRascan I: MTHFR and TYMS genotypes influence TPMT activity and its differential modulation in males and females. Clin Biochem 2010;43:37-42.

32 Rozen R, Fraser FC, Shaw G: Decreased proportion of female newborn infants homozygous for the $677 \mathrm{C}-\mathrm{T}$ mutation in methylenetetrahydrofolate reductase. Am J Med Genet 1999;83:142-143.

33 Satlin LM, Guay-Woodford L, Chevalier RL: Proceedings of the Eighth International Workshop on Developmental Nephrology: genes, morphogenesis, and function. The sessions. Pediatr Nephrol 2003;18:174-195.

34 Chen F: Genetic and developmental basis for urinary tract obstruction. Pediatr Nephrol 2009:24:1621-1632.

35 Grote D, Boualia SK, Souabni A, Merkel C, Chi X, et al: Gata3 acts downstream of betacatenin signaling to prevent ectopic metanephric kidney Induction. PLoS Genet 2008; 4:e1000316.

36 Bates CM: Role of fibroblast growth factor receptor signaling in kidney development. Pediatr Nephrol 2007;22:343-349.
37 Michos O, Gonçalves A, Lopez-Rios J, Tiecke E, Naillat F, Beier K, Galli A, Vainio S, Zeller R: Reduction of BMP4 activity by gremlin 1 enables ureteric bud outgrowth and GDNF/ WNT11 feedback signalling during kidney branching morphogenesis. Development 2007;134:2397-2405.

- 38 Miyazaki Y, Oshima K, Fogo A, Ichikawa I: Evidence that bone morphogenetic protein 4 has multiple biological functions during kidney and urinary tract development. Kidney Int 2003;63:835-844.

39 Basson MA, Akbulut S, Watson-Johnson J, Simon R, Carroll TJ, Shakya R, Gross I, Martin GR, Lufkin T, McMahon AP, Wilson PD, Costantini FD, Mason IJ, Licht JD: Sproutyl is a critical regulator of GDNF/RET-mediated kidney induction. Dev Cell 2005;8:229-239.

40 Uetani N, Bouchard M: Plumbing in the embryo: developmental defects of the urinary tracts. Clin Genet 2009;75:307-317.

-41 Lu W, Quintero-Rivera F, Fan Y, Alkuraya FS, Donovan DJ, Xi Q, Turbe-Doan A, Li QG, Campbell CG, Shanske AL, Sherr EH, Ahmad A, Peters R, Rilliet B, Parvex P, Bassuk AG, Harris DJ, Ferguson H, Kelly C, Walsh CA, Gronostajski RM, Devriendt K, Higgins A, Ligon AH, Quade BJ, Morton CC, Gusella JF, Maas RL: NFIA haploinsufficiency is associated with a CNS malformation syndrome and urinary tract defects. PLoS Genet 2007;3:e80.

42 Stahl DA, Koul HK, Chacko JK, Mingin GC: Congenital anomalies of the kidney and urinary tract (CAKUT): a current review of cell signaling processes in ureteral development. J Pediatr Urol 2006;2:2-9.

-43 Ormond G, Nieuwenhuijsen MJ, Nelson P, Toledano MB, Iszatt N, Geneletti S, Elliott P: Endocrine disruptors in the workplace, hair spray, folate supplementation, and risk of hypospadias: case-control study. Environ Health Perspect 2009;117:303-307.

44 Beaudin AE, Stover PJ: Insights into metabolic mechanisms underlying folate-responsive neural tube defects: a minireview. Birth Defects Res A Clin Mol Teratol 2009;85:274-284.

45 Bourc'his D, Proudhon C: Sexual dimorphism in parental imprint ontogeny and contribution to embryonic development. Mol Cell Endocrinol 2008;282:87-94.

46 Farthing CR, Ficz G, Ng RK, Chan CF, Andrews S, Dean W, Hemberger M, Reik W: Global mapping of DNA methylation in mouse promoters reveals epigenetic reprogramming of pluripotency genes. PLoS Genet 2008;4:e1000116.

47 Zeisel SH: Importance of methyl donors during reproduction. Am J Clin Nutr 2009;89: 673S-677S

48 Deak KL, Siegel DG, George TM, Gregory S, Ashley-Koch A, Speer MC, NTD Collaborative Group: Further evidence for a maternal genetic effect and a sex-influenced effect contributing to risk for human neural tube defects. Birth Defects Res A Clin Mol Teratol 2008;82:662-669. 